\title{
DA INCOMPETÊNCIA DA JUSTIÇA DO TRABALHO PARA PROSSEGUIR COM AS EXECUÇÕES TRABALHISTAS APÓS A DECRETAÇÃO DA FALÊNCIA A SOCIEDADE EMPRESÁRIA
}

\section{THE INCOMPETENCE OF LABOUR COURT TO PROCEED WITH THE EXECUTIONS OF THE LABOUR PROCESSES AFTER DECLARED BANKRUPTCY OF THE COMPANY}

\author{
${ }^{1}$ Érika Santiago Silva
}

\section{RESUMO}

A lei 11.101/05, ao tratar da falência das sociedades empresárias, invoca como postulados básicos os princípios da universalidade e indivisibilidade do juízo falimentar, além do princípio da par conditio creditorum. Ocorre que a Justiça do Trabalho, desrespeitando o propósito da Lei Falimentar, e em flagrante violação aos princípios mencionados, insiste em prosseguir com as execuções das ações trabalhistas propostas contra a sociedade empresária falida, ultrapassando os limites de sua competência, portanto, de forma completamente arbitrária, promovendo a desconsideração da personalidade jurídica de forma a atingir o patrimônio pessoal dos sócios da falida. Tal expediente pode causar prejuízos à massa falida, uma vez que, caso apurada a responsabilidade dos sócios falidos, estes já não mais terão patrimônio a ser arrecadado pela massa falida, ou seja, todo o seu patrimônio já terá sido excutido em prol unicamente dos credores trabalhistas, ofendendo, assim, a paridade com que devem ser tratados os credores.

Palavras-chave: Falência, Crédito trabalhista, Par conditio creditorum, Juízo falimentar, Juízo trabalhista, Competência

\begin{abstract}
The 11.101/05 Law, when dealing with the bankruptcy of commercial companies, as basic postulates invokes the principles of universality and indivisibility of the bankruptcy court, beyond the principle of par conditio creditorum. However, the Labour Court, disregarding the purpose of the Bankruptcy Law, and in flagrant violation of the mentioned principles, insists on proceeding with the executions of the labor processes proposed against the bankrupt company, surpassing the limits of their competence, thus so completely arbitrary, piercing the corporate veil in order to reach the personal patrimony of the shareholders of the company. This practice may prejudice the bankruptcy, since, if ascertained the liability of bankrupt partners, they will no longer have patrimony to be raised by the bankruptcy, because all of its property have been realized in favor only of labor creditors, thus offending the equality that all the creditors must be treated.
\end{abstract}

Keywords: Bankruptcy, Labor credit, Par conditio creditorum, Bankruptcy court, Labor court, Jurisdiction

\footnotetext{
${ }^{1}$ Especialização em Perícia Contábil e Financeira na Universidade Estácio de Sá - UNESA, Minas Gerais, MG, (Brasil).. E-mail.: erika.admjud@yahoo.com.br
} 


\section{INTRODUÇÃO}

A Lei 11.101/05, que revogou o Decreto-Lei 7.661/45, inovou com relação ao tratamento dispensado às sociedades empresárias em estado de insolvência, mantendo, todavia, os principais postulados que devem nortear todo o processamento das ações de falência.

O processo falimentar, como sabido, se orienta pelo princípio maior da par conditio creditorum, que determina que deve haver uma paridade de tratamento entre os credores. $\mathrm{Ou}$ seja, todos os credores devem ser tratados de forma igualitária, respeitando, todavia, as diversas classes, concorrendo ao juízo universal da falência para ter sua participação no rateio do ativo arrecadado.

É esse o princípio que rege todo o processo falimentar e faz (ou pelo menos deveria fazer) com que as demais regras a ele se subordinem.

O princípio da paridade legitima a criação do processo de execução coletiva, de forma a proporcionar, repita-se, tratamento igualitário aos credores. de uma mesma classe.

Não obstante ser esse o princípio cardeal do processo falimentar, e que deveria ser comum a toda a execução concursal, ele tem sido comumente mitigado na Justiça Trabalhista.

O que se observa com grande frequência é que nas ações trabalhistas, após apurado o crédito líquido, as respectivas execuções têm sido processadas na própria Justiça Laboral, em afronta aos princípios da par conditio creditorum, bem como da unidade e indivisibilidade do juízo falimentar.

Essa prática vem causando prejuízos aos demais credores da sociedade empresária falida, àqueles de outras classes e até mesmo aos credores trabalhistas, os quais, seguindo os postulados básicos do Direito Falimentar, habilitam seus créditos junto à massa.

E isso ocorre porque, na Justiça do Trabalho, os juízes, extrapolando os limites de sua competência em matéria falimentar, vêm se utilizando do instituto da disregard doctrine de forma a atingir o patrimônio pessoal dos sócios e daqueles responsáveis pela gestão da sociedade falida.

Há também hipóteses em que a desconsideração da personalidade jurídica atinge outras sociedades empresárias, quando se trata de mesmo grupo econômico, de forma a arrecadar o patrimônio destas em busca da satisfação dos créditos trabalhistas.

Nesse sentido, mais rapidamente são satisfeitos os créditos desses credores trabalhistas em detrimento dos demais credores que, acaso apurada a responsabilidade civil 
dos sócios e dirigentes da falida, possivelmente não mais encontrarão patrimônio disponível para a satisfação de seus créditos.

Assim, na prática, enquanto alguns credores (na justiça laboral) vêm recebendo seus créditos através da expropriação do patrimônio pessoal dos sócios da falida, ou de eventuais sociedades empresárias pertencentes ao mesmo grupo econômico, outros estão a aguardar o moroso procedimento falimentar, para, quem sabe algum dia, receberem seus créditos. Essa situação configura, a nosso ver, nítida violação ao já mencionado princípio da par conditio creditorum, o que não pode ser admitido.

Ou seja, a desconsideração da personalidade jurídica da sociedade empresária falida, comumente deferida nas execuções de créditos trabalhistas perante a Justiça do Trabalho, além de violar o princípio norteador da par conditio creditorum, também viola as regras de competência em matéria falimentar (universalidade e indivisibilidade do juízo falimentar).

O presente trabalho tem, assim, por objetivo, a realização de um estudo do instituto da falência e dos princípios que a norteiam, bem como da disregard doctrine e de sua utilização pela Justiça do Trabalho nas ações/execuções envolvendo créditos trabalhistas sujeitos ao concurso de credores, bem como propor uma reflexão acerca dessa prática que vem se tornando comum, e que representa uma alternativa para se burlar a paridade com que devem ser tratados os credores no juízo falimentar, de forma a beneficiar uns em detrimento de outros, possibilitando, ainda, a ocorrência de inúmeras fraudes.

A metodologia utilizada será a revisão bibliográfica, principalmente em matéria de Direito Processual do Trabalho e Direito Empresarial, com foco na Lei 11.101/05.

Também serão estudados os diplomas legais que se relacionam às questões trazidas à baila.

Propõe-se, ademais, um estudo do caminhar jurisprudencial envolvendo a questão, através de um cotejo de decisões de diversos Tribunais, de forma a se delinear a tendência que vem sendo adotada.

\section{O INSTITUTO DA FALÊNCIA E OS PRINCÍPIOS DA UNIVERSALIDADE E INDIVISIBILIDADE DO JUÍZO FALIMENTAR}

Falir, do latim fallere, significa suspender os pagamentos, não ter como pagar os credores.Já a noção jurídica de falência quer dizer a execução coletiva da sociedade empresária devedora, à qual concorrem todos os credores, e que tem por objetivo a 
arrecadação de todo o seu ativo para posterior liquidação e pagamento dos credores, segundo a ordem legal de preferência.

Nos dizeres Valverde (1999, p.7),

O instituto da falência é o complexo de regras jurídicas, técnicas ou construtivas, que definem e regulam uma situação especial, de ordem econômica, a falência.

Juridicamente, a falência se caracteriza por atos ou fatos que denotam, comumente, um desequilíbrio no patrimônio do devedor.

Essas regras técnicas ou construtivas são uma criação da lei positiva e têm na norma geral de que o patrimônio do devedor é a garantia comum dos credores, o seu fundamento.

Ou seja, o instituto da falência surgiu como um conjunto de normas jurídicas aptas a regular a situação do devedor em crise, no momento em que se forma um processo de execução coletiva. Tais regras destinam a tutelar não só o interesse privado (principalmente dos credores em execução coletiva), mas também o interesse público, notadamente no que respeita à defesa exercida pelo Estado com relação aos atos e omissões delituosos em matéria falimentar, que ofendem a boa-fé das partes e o crédito público.

A falência, repita-se, é um processo de execução coletiva universal, que abrange todos os credores e todos os bens do devedor. Se a sociedade empresária, sem relevante razão de direito, não pagar no vencimento obrigação líquida, constante de titulo executivo, estará sujeita à execução coletiva universal. Nesse caso, todos os bens do falido serão arrecadados e todos os seus credores podem pedir execução, independentemente de qualquer sentença anterior.

Tem-se, assim, que a falência é um instituto jurídico complexo, que visa liquidar as obrigações do devedor inadimplente ou insolvente, por meio de um processo de execução coletiva em que se arrecadam todos os bens do devedor falido, visando o pagamento dos credores, respeitadas a ordem e preferências legais.

$\mathrm{Na}$ base desse instituto encontram-se dois princípios básicos: o da unidade (indivisibilidade) do juízo falimentar e o da universalidade desse estado jurídico. Juntos, estes princípios garantem a fixação de um processo de execução coletiva perante uma única autoridade, a generalidade de seus efeitos e a par conditio creditorum.

O princípio da universalidade implica a abrangência de todos os bens do devedor e de todos os seus credores. Daí tratar-se de uma execução coletiva.

Isso implica que todos os credores do falido (credores civis e "comerciais") devem concorrer ao juízo universal, único e geral. 
Como o patrimônio é único, o juízo falimentar também deve ser único, e a execução coletiva também deve ser única.

Daí se falar também em unidade do juízo falimentar, que implica seu caráter unitário, ou seja, só pode haver um único juízo falimentar para um mesmo devedor, pouco importando que ele possua estabelecimentos em diversos outros municípios, ou mesmo Estados da Federação.

Na esteira desse princípio, um único juízo será competente para julgar qualquer ação que tenha como alvo bens, interesses ou negócios da empresa falida, ressalvadas as exceções trazidas na própria Lei.

O juízo da falência é, assim, indivisível. Não pode ser fracionado; não pode haver pluralidade de juízos falenciais.

Fátima Nancy Andhrighi, na obra Comentários à nova lei de falência e recuperação de empresas: Lei 11.101/05, de 09 de fevereiro de 2005, coordenada por Osmar Brina CorrêaLima e Sérgio Mourão Corrêa Lima (2009, p.500), ensina:

Essas regras, em conjunto, têm como finalidade: (i) impedir que sejam declaradas tantas falências em juízos diferentes quantos sejam os estabelecimentos do devedor; e (ii) evitar a dispersão de ações de caráter patrimonial a serem propostas contra a massa falida, submetendo todas a critério de um único julgamento.

O juízo da falência é, assim, universal, uma vez que a ele devem se dirigir todos os credores, com vistas à satisfação dos seus créditos; e é indivisível, na medida em que é o único competente para dirimir os conflitos entre os credores e o devedor insolvente, assim declarado judicialmente, julgando todas as ações que envolvam interesses da sociedade empresarial falida.

Não se olvida, portanto, que a necessidade de um único juízo competente para o julgamento de todas as ações patrimoniais propostas contra a massa falida tem como fundamento o princípio da par conditio creditorum, já que somente estando sujeitos a um mesmo juízo os credores serão tratados em condição de igualdade.

Nas palavras de Requião (1989):

(...) pela natureza coletiva do processo de falência e pelo princípio da par condicio creditorum todos os credores que ocorrem ao processo de falência devem ser tratados com igualdade em relação aos demais credores da mesma categoria. Somente a unidade e a universalidade do juízo poderiam assegurar a realização dessas regras.

Apropriado é o magistério de Coelho (2005, p. 201), ao dizer que 
(...) o juízo da falência é universal. Isso significa que todas as ações referentes aos bens, interesses e negócios da massa falida serão processadas e julgadas pelo juízo perante o qual tramita o processo de execução concursal por falência. É a chamada aptidão atrativa do juízo falimentar, ao qual conferiu à lei a competência para conhecer e julgar todas as medidas judiciais de conteúdo patrimonial referentes ao falido ou à massa falida.

Da mesma forma, explica o mesmo autor, em outra obra :

O juízo falimentar é universal, porque atrai todas as ações e interesses da sociedade falida e da massa falida. A atratividade do juízo falimentar não se verifica relativamente às ações não reguladas pela Lei de Falências de que seja autora ou litisconsorte ativa a massa falida, às que demandam quantia ilíquida ou às execuções fiscais. Também não ocorre a atração prevista em lei se a competência jurisdicional é ditada pela Constituição (Justiça do Trabalho e Justiça Federal). (COELHO, 2005, p.263).

Não se olvida, portanto, da necessidade de um único juízo para tratar de todas as ações envolvendo a sociedade empresária falida, perante o qual deve ocorrer a arrecadação de todo o ativo e, ainda, concorrerem todos os credores.

Sobreleve-se, todavia, que a vis attractiva do juízo falimentar não é absoluta, encontrando ressalvas no próprio artigo 76 da Lei falimentar, o que será objeto de estudo mais adiante.

\section{A VIS ATTRACTIVA DO JUÍZO FALIMENTAR E A COMPETÊNCIA DA JUSTIÇA TRABALHISTA}

Como já dito, o juízo da falência é universal e indivisível, implicando dizer que nele se processam todas as ações contra o devedor, bem como que é perante este juízo que deverão ser arrecadados todos os ativos da sociedade empresária falida e feito o pagamento a todos os credores, de forma a se respeitar o princípio da par conditio creditorum.

Ora, a unidade e indivisibilidade do juízo falimentar decorrem da disposição legal contida no $\S 8^{\circ}$, do art. $6^{\circ}$ c/c o art. 76, ambos da Lei $n^{\circ} 11.101 / 2005$.

Dispõe o $\S 8^{\circ}$, do art. $6^{\circ}$ que
A distribuição do pedido de falência ou de recuperação judicial previne a jurisdição para qualquer outro pedido de recuperação judicial ou de falência, relativo ao mesmo devedor.

O art. 76 da L. 11.101/2005, por sua vez, disciplina: 


\begin{abstract}
O Juízo da falência é indivisível e competente para conhecer todas as ações sobre bens, interesses e negócios do falido, ressalvadas as causas trabalhistas, fiscais e aquelas não reguladas nesta Lei em que o falido figurar como autor ou litisconsorte ativo.
\end{abstract}

Da análise do art. 76 acima transcrito infere-se que, a despeito da vis attractiva, há algumas ações que não são atraídas pelo juízo falimentar, dentre as quais podemos mencionar as ações trabalhistas, que são objeto de estudo neste trabalho.

Segundo a regra de competência estabelecida no art. 114 da Constituição Federal, referidas ações devem tramitar perante a justiça laboral.

Dispõe o inciso I do art. 114 da CR/88, verbis:

\begin{abstract}
Art. 114. Compete à Justiça do Trabalho processar e julgar: (Redação dada pela Emenda Constitucional no 45 , de 2004)

I as ações oriundas da relação de trabalho, abrangidos os entes de direito público externo e da administração pública direta e indireta da União, dos Estados, do Distrito Federal e dos Municípios; (Incluído pela Emenda Constitucional no 45 , de 2004)

(...).
\end{abstract}

Por força do que dispõe o art. 114, a justiça laboral é o único órgão do Poder Judiciário com competência para julgar os dissídios oriundos das relações de trabalho, ou seja, todos os conflitos decorrentes das relações disciplinadas pela legislação trabalhista, independentemente da existência de um processo falimentar, devem ser processadas e julgadas na Justiça do Trabalho.

Assim, se no curso de uma ação trabalhista sobrevier a falência do empregador, referida ação não será atraída para o juízo da falência, em razão da manifesta incompetência ratione materiae deste.

Mas essa questão não é tão simplista como parece.

É que, em relação à fase de conhecimento das ações trabalhistas, a questão não comporta dúvidas: a competência é da Justiça do Trabalho. Também é desta Justiça a competência para promover eventual liquidação dos créditos.

Todavia, quando estamos diante da etapa em que se promoverá a execução desses créditos é que surgem as controvérsias, que não são poucas.

Muito embora o entendimento predominante na doutrina seja no sentido de que a competência da Justiça do Trabalho se limita à fase de conhecimento, ou seja, as execuções 
os créditos trabalhistas devem ser submeter ao concurso falimentar, não é isso o que se tem observado na prática. Essa justamente a questão objeto deste trabalho.

Conforme demonstraremos adiante, hoje há um grande número de juízes trabalhistas que, desconsiderando por completo o princípio da universalidade do juízo falimentar e, em última análise, o da par conditio creditorum, dão prosseguimento, de forma completamente independente e alheio ao procedimento falimentar, às execuções dos créditos trabalhistas.

Todavia, defendemos que tal expediente, por implicar grande ofensa ao objetivo maior da execução concursal que é, repita-se, a paridade entre os credores, deve ser repudiado como prática que vem se tornando rotineira em grande parte da Justiça Laboral.

\section{O PRINCÍPIO DA PAR CONDITIO CREDITORUM}

Como já ressaltado alhures, o artigo 76 da Lei 11.101/05 trás em si importantes princípios a serem observados quando da decretação da falência, quais sejam, a unicidade, indivisibilidade e universalidade do juízo. Tais princípios informadores devem estar presentes em qualquer procedimento concursal, porquanto, sem sua observância, não se consegue atingir os seus fins (da execução concursal).

E é visando atingir os fins buscados pela Lei de Falências que, ao concentrar em apenas um juízo todas as ações e execuções movidas em face do falido, o legislador buscou garantir um tratamento igualitário aos credores da massa falida, privilegiando, assim, o princípio maior inspirador do procedimento concursal que é o da par conditio creditorum.

Segundo a par conditio creditorum, todos os credores devem ter tratamento igualitário de forma que a nenhum seja dado tratamento privilegiado em detrimento dos interesses dos demais.

Por óbvio que esse tratamento igualitário a que nos referimos deve observar as desigualdades existentes entre os credores, que deverão ser classificados em classes distintas, segundo os ditames legais.

Nos dizeres de Tomazette (2014, p.277):

\footnotetext{
A falência é um processo de execução coletiva contra o devedor empresário e, nessa condição, ela visa ao pagamento de todos os credores e não apenas de alguns. Como raramente haverá recursos suficientes para o pagamento de todos, o processo de falência organiza os credores em classes e efetua o pagamento de acordo com uma ordem de importância. A ideia é dar um tratamento melhor a quem merece mais proteção, evitando uma situação de desigualdade entre os credores.
} 


\begin{abstract}
Quem passa por uma crise econômico-financeira raramente consegue pagar todos os seus credores. Em razoa disso, é comum que os empresários em crise optem pelo pagamento de certos credores, deixando outros sem receber. De outro lado, os credores não pagos tendem a tomar as medidas necessárias para a satisfação do seu credito, mas apenas os mais ágeis tendem a ter sucesso. Em última análise, a tendência normal é que alguns credores recebam e outros fiquem insatisfeitos, sem um critério para saber quais serão pagos ou não.

A falência, ao instituir uma execução coletiva, tenta afastar essa desigualdade, impondo um tratamento igualitário entre os credores. Esse tratamento igualitário não significa que todos os credores terão o mesmo tratamento, mas que todos os credores em situação igual terão o mesmo tratamento e os credores em situação desigual terão tratamento desigual. (...)

Fala-se em aplicação da par conditio creditorum, no sentido de que todos os credores terão direitos iguais no processo de falência, ressalvadas as preferências estabelecidas pela legislação.
\end{abstract}

Não se olvida, portanto, a preocupação do legislador com a garantia da par conditio creditorum aos credores da massa falida, pois, caso fosse permitida a execução individual de cada crédito, a própria Lei de Falências perderia sua razão de existir.

E é justamente esse o ponto nodal deste trabalho.

Se fosse dado aos credores trabalhistas executarem seus créditos individualmente, em detrimento dos demais credores da massa, estar-se-ia pondo por terra o princípio da par conditio creditorum e, por conseguinte, o próprio objetivo da execução concursal.

E isso porque os credores trabalhistas, na execução individual de seus créditos, longe do concurso de credores imposto pela lei falimentar, poderão, inclusive, arrecadar os bens individuais dos sócios da falida e de outras empresas, caso se trate de grupo econômico, impossibilitando que estes bens sejam futuramente arrecadados pela massa, na hipótese de responsabilização pessoal dos sócios ou de desconsideração da personalidade jurídica e extensão dos efeitos da falência.

Ora, além do risco de estes credores trabalhistas, por meio das execuções individuais de seus créditos, esvaziarem o patrimônio da massa, há ainda o risco de eles perseguirem o patrimônio individual dos sócios da devedora falida, ou de outras empresas pertencentes ao mesmo grupo econômico, por meio do instituto da disregard doctrine, retirando também da massa a possibilidade de, uma vez responsabilizados os sócios/administradores da sociedade empresária falida, ou na hipótese de se promover a desconsideração da personalidade jurídica no juízo falimentar, arrecadar os bens particulares destes.

Nessas hipóteses, os credores trabalhistas garantiriam, ao menos em parte, o recebimento de seus créditos, enquanto aqueles que se sujeitaram ao moroso procedimento da Lei 11.101/05 ficariam sem qualquer participação no produto da arrecadação dos bens particulares dos sócios ou de outras empresas responsabilizadas pelo juízo falimentar. 
Isso implica dizer que a execução individual dos créditos trabalhistas traz uma grande vantagem para estes credores, em detrimento e desprestígio dos demais, que se valeram do procedimento legal, em flagrante violação à paridade entre os credores que deve nortear todo esse procedimento falimentar.

\section{OS LIMITES DA COMPETÊNCIA DA JUSTIÇA TRABALHISTA NAS AÇÕES CONTRA SOCIEDADE EMPRESÁRIA FALIDA}

O presente trabalho, como já dito, propõe uma reflexão acerca dos limites da competência da Justiça do Trabalho no que se refere às ações contra uma sociedade empresária falida.

Questão bastante tormentosa, uma vez que reflete diretamente nos direitos dos credores em regime concursal.

Como já dito, o instituto da falência implica uma execução coletiva contra a sociedade empresária devedora, quando então ocorre a arrecadação de todo o seu ativo, para futura alienação e pagamento de todos os seus credores, respeitando-se a ordem de preferência legal. Tudo isso perante um juízo único e indivisível.

Com efeito, o objetivo maior da execução coletiva é justamente dar tratamento igualitário a todos os credores, de forma a não privilegiar alguns em detrimento dos demais. Esse o fundamento do princípio da par conditio creditorum, que justifica a instauração de um juízo falimentar universal.

Ocorre que, conforme já visto, há exceções à universalidade do juízo falimentar, dentre as quais podemos citar as ações decorrentes das relações de trabalho que, segundo dispõe o art. 114 da Constituição Federal, devem ter seu prosseguimento perante a Justiça do Trabalho.

Assim, todas as ações envolvendo relações de trabalho, propostas antes ou após a decretação da quebra, devem se processar na justiça laboral. O dispositivo não deixa dúvidas quanto às ações de conhecimento.

Todavia, quando estamos diante das execuções dos créditos trabalhistas é que surge o problema: habilitá-las na falência ou prosseguir com as respectivas execuções na própria justiça laboral?

A despeito dessa regra de competência constitucionalmente estabelecida (art. 114 da $\mathrm{CF} / 88$ ), a intepretação que mais coaduna com o fim maior da lei falimentar é a de que, uma 
vez apurado o crédito liquido na justiça laboral, sua execução, assim como a de todos os demais créditos, deve se dar de forma concursal, perante o juízo único e universal da falência.

Com efeito, as disposições contidas na Lei 11.101/05 quanto à universalidade, unicidade e indivisibilidade do juízo falimentar não deixam dúvidas sobre os limites da competência trabalhista em caso de falência do devedor principal, sendo essa competência limitada à apuração do crédito decorrente da justiça do trabalho.

Nos dizeres de Fátima Nancy Andrighi, comentando a Lei 11.101/05,

\begin{abstract}
Quanto aos créditos trabalhistas, da mesma forma, a interpretação dada à legislação anterior era no sentido de que permaneceria sendo promovida perante a Justiça do Trabalho. Alguma controvérsia se formou a respeito da competência para a execução do montante apurado pelo Juízo Trabalhista, mas a jurisprudência pacificou no sentido de competir à Justiça do Trabalho processar e julgar a reclamação trabalhista, e ao juízo falimentar somente promover a respectiva execução. Nesse sentido foram as decisões exaradas pelo Superior Tribunal de Justiça por ocasião do julgamento dos Conflitos de Competência $\mathrm{n}^{\circ}$ 14.559/SP (DJ de 22.04.1996), 34.635/GO (DJ de $1^{\circ} .3 .2004$ ) e AgRg no CC no 46.928/SP (DJ de 13.10.2005).

No mesmo sentido, a Segunda Seção do STJ estabeleceu que "os atos praticados na liquidação, e não na execução, podem ser efetivados na justiça laboral. A execução processar-se-á no juízo universal da falência."

Não ha motivos para que esse entendimento se modifique com a vigência da nova LRE. As alterações trazidas em relação a estas questões vieram meramente consagrar o entendimento que estava consolidado, de modo a tornar mais clara a preservação da competência dos Juízos fiscal e trabalhista. (LIMA, 2009, p. 503).
\end{abstract}

No mesmo sentido os ensinamentos de Mauro Rodrigues Penteado:

No tocante às reclamatórias trabalhistas já ajuizadas, a despeito da péssima redação do artigo, há que prevalecer a regra geral mencionada no item 67, acima, que determina o prosseguimento das ações que demandarem quantia ilíquida, durante o período de suspensão das demais ações. Ou seja, as ações trabalhistas prosseguem no juízo especializado em que estão sendo processadas, até a quantificação do crédito, para posterior inscrição no Quadro-Geral de Credores do juízo universal, por força do mesmo art. $6^{\circ}, \S 2^{\circ}$, parte final. Com a garantia do pedido de reserva que aquele juízo de origem pode determinar ao juízo universal $\left(\operatorname{art.} 6^{\circ}, \S^{\circ}\right)$. (JUNIOR, 2007, p.139).

Ocorre que, muito embora esse entendimento pareça estar sedimentado, não é isso o que se observa, com grande frequência, na Justiça Laboral que, dado seu caráter histórico paternalista e protecionista dos interesses do empregado, acaba por violar as disposições legais previstas na LRF, expandindo sua competência para além dos limites impostos pela Constituição.

Em outras palavras, não são poucas as decisões proferidas pelos juízes trabalhistas que, paralelamente, e em afronta ao juízo universal da falência, deferem o prosseguimento das 
execuções trabalhistas na própria justiça laboral, ignorando por completo a existência de um concurso universal que, necessariamente, teria que ser observado.

Como se pode ver, os juízes trabalhistas vêm mitigando as normas e princípios que disciplinam as execuções concursais, conferindo ainda mais privilégios aos créditos trabalhistas (que já têm assegurado um tratamento privilegiado na falência, justamente por estarmos diante de verbas de natureza alimentar) em detrimento dos demais credores.

Com efeito, o art. 114 da Constituição Federal não pode abrir tamanho precedente; esta não foi, por certo, a intenção do legislador.

Conforme os ditames legais, repita-se, quando decretada a falência, todas as ações que envolvam bens, interesses e negócios do falido, serão direcionadas ao juízo falimentar, que se torna, assim competente para todas as questões envolvendo a massa falida; daí o nome juízo universal.

Nesse sentido, defendemos o posicionamento de que, em relação às causas trabalhistas, uma vez proferida a sentença e apurado o crédito líquido na justiça laboral, este crédito deverá, após analisado pelo administrador judicial e devidamente habilitado, ser executado no juízo falimentar.

Esse também o posicionamento defendido por GONTIJO (2007) que assim discorreu, citando Celso Agrícola Barbi:

\footnotetext{
Celso Agrícola Barbi já anotava que "a finalidade da competência em razão da matéria é especializar os juízes, propiciando, assim, meios para o aprimoramento do trabalho da magistratura". Por isso, nosso legislador constitucional, no artigo 114 da $\mathrm{CF}$, prescreveu a competência material da Justiça do Trabalho.

No entanto, estando prestada a jurisdição especial material, a execução da obrigação acertada e liquidada não demanda a especialização judicial trabalhista, podendo (e devendo), ao revés, ser aplicada pelo Poder Judiciário incumbido especialmente da execução coletiva falimentar, assegurando a par conditio creditorum inclusive em favor dos demais empregados incluídos no quadro geral de credores da massa falida. (...)

Nesse sentido, a doutrina já reconhece a constitucionalidade da competência do juízo falimentar para o cumprimento da obrigação sentenciada na Justiça do Trabalho. (BARBI, 1997, apud GONTIJO, 2007).
}

Aqueles que defendem a posição contrária, no sentido de que a execução dos créditos trabalhistas deve se processar na própria Justiça do Trabalho, baseiam-se no art. 114 da Constituição Federal, dizendo que é competente para julgar e executar a sentença o juízo trabalhista, vez que a execução não é processo autônomo mais sim continuação do processo de conhecimento.Não se olvida que o artigo 114 da CF cria a competência da Justiça do Trabalho como única para julgar os dissídios oriundos da relação empregatícia e do trabalho. 
Mas essa competência constitucionalmente estabelecida, segundo o que defendemos, não deve se estender à fase de execução dos créditos trabalhistas, em razão de um princípio maior que é o da par conditio creditorum.

E uma das teses que pode ser adotada em defesa desse posicionamento é justamente a que foi invocada pelo Ministro Ricardo Lewandowski, Relator do Recurso Extraordinário no $583.955-9 / \mathrm{RJ}$.

No julgamento do referido recurso ${ }^{1}$ o Ministro Relator colocou uma pá de cal sobre a questão até então controvertida, ao declarar a competência absoluta da Justiça Comum para a execução de créditos trabalhistas em processos de falência e recuperação judicial. No voto condutor do julgamento, o Min. Lewandowski consignou que

\begin{abstract}
(...) as regras hoje vigentes, assim como as passadas, consagram o princípio da universalidade do juízo falimentar, que exerce uma vis attractiva sobre todas as ações de interesse da massa falida, caracterizando sua indivisibilidade. É que num processo falimentar o patrimônio da empresa nem sempre equivale ao montante de dívidas, razão pela qual a regra da indivisibilidade na execução de créditos, que prevalece em situações de normalidade, poderia levar a que determinados credores obtivesses vantagem indevida relativa a outros, em detrimento da isonomia que deve imperar entre eles, no tocante à liquidação de haveres. Em outras palavras, os credores que primeiro ingressassem com a execução seriam impropriamente privilegiados em prejuízo dos demais.
\end{abstract}

O Ministro ressaltou, ainda, a necessidade de instauração de um juízo universal, sob pena de afronta ao princípio da par conditio creditorum, assim consignando:

(...) a execução deixa de ser feita individualmente, passando a ser realizada de forma comum. Essa sistemática permite que se materialize, na prática, o vetuso princípio

\footnotetext{
1 “CONFLITO NEGATIVO DE COMPETÊNCIA. EXECUÇÃO DE CRÉDITOS TRABALHISTAS EM PROCESSOS DE RECUPERAÇÃO JUDICIAL. COMPETÊNCIA DA JUSTIÇA ESTADUAL COMUM, COM EXCLUSÃO DA JUSTIÇA DO TRABALHO. INTERPRETAÇÃO DO DISPOSTO NA LEI 11.101/05, EM FACE DO ART. 114 DA CF . RECURSO EXTRAORDINÁRIO CONHECIDO E IMPROVIDO. I - A questão central debatida no presente recurso consiste em saber qual o juízo competente para processar e julgar a execução dos créditos trabalhistas no caso de empresa em fase de recuperação judicial. II - Na vigência do Decreto-lei 7.661/1945 consolidou-se o entendimento de que a competência para executar os créditos ora discutidos é da Justiça Estadual Comum, sendo essa também a regra adotada pela Lei 11.101/05. III - O inc. IX do art. 114 da Constituição Federal apenas outorgou ao legislador ordinário a faculdade de submeter à competência da Justiça Laboral outras controvérsias, além daquelas taxativamente estabelecidas nos incisos anteriores, desde que decorrentes da relação de trabalho. IV - O texto constitucional não o obrigou a fazê-lo, deixando ao seu alvedrio a avaliação das hipóteses em que se afigure conveniente o julgamento pela Justiça do Trabalho, à luz das peculiaridades das situações que pretende regrar. IV - A opção do legislador infraconstitucional foi manter o regime anterior de execução dos créditos trabalhistas pelo juízo universal da falência, sem prejuízo da competência da Justiça Laboral quanto ao julgamento do processo de conhecimento . (Recurso extraordinário conhecido e improvido. " Recurso Extraordinário no 583.955-9 Rio de Janeiro, Ministro Relator Ricardo Lewandowski, Tribunal Pleno do STF, julgado em 28 de maio de 2009, publicado no Diário de Justiça Eletrônico de 28 de agosto de 2009.) Disponível em: http://redir.stf.jus.br/paginadorpub/paginador.jsp?docTP=AC\&docID=601787. Acesso em: 29/03/2015, às $00: 36 \mathrm{~h}$
} 
da par conditio creditorum, o qual assegura tratamento paritário a todos os credores de uma mesma categoria na percepção daquilo que lhes é devido.

E para justificar o posicionamento então adotado, o Ministro Lewandowski, em seu voto, esclareceu que o inciso IX do art. 114 da Constituição Federal, ao dispor sobre a competência da Justiça do Trabalho, outorgou ao legislador ordinário apenas a faculdade de submeter à competência da Justiça Laboral outras controvérsias, além daquelas taxativamente estabelecidas nos incisos anteriores, desde que decorrentes da relação de trabalho.

Registre-se que nenhum inciso anterior consigna de forma expressa que a Justiça Trabalhista seria competente para prosseguir com as execuções de créditos líquidos devidos por uma sociedade empresária falida.

Em outras palavras, se ao legislador ordinário coube a faculdade de atribuir à Justiça do Trabalho a competência para julgar outras ações decorrentes da relação de trabalho, e se ele nada dispôs acerca das execuções de créditos trabalhistas quando há decretação de falência do devedor principal, é porque não entendeu conveniente fazê-lo, à luz dos valores e princípios em jogo, no caso, aqueles já mencionados, afetos à própria essência do procedimento falimentar.

O que se vê, portanto, é que o STF, em maio de 2009, ou seja, após a Lei 11.101/05, manifestou-se no sentido de que a execução dos créditos trabalhistas deve se processar perante o juízo universal da falência, juntamente com as demais execuções contra o devedor falido, de forma a se respeitar, insista-se, a paridade entre referidos credores.

Nessa linha de raciocínio, não cabe aos juízes do trabalho promover a desconsideração da personalidade jurídica da sociedade empresária falida, com vistas à persecução do patrimônio individual de seus sócios ou, eventualmente, de outras sociedades empresárias pertencentes ao mesmo grupo econômico, para a satisfação dos credores trabalhistas que deixaram de habilitar seus créditos junto ao juízo universal.

Com efeito, esse expediente que vem sendo comumente utilizado na justiça laboral a disregard doctrine - não pode ser aceito quando se tratar de empregador falido, por absoluta ausência de previsão legal, além de flagrante ofensa ao próprio sentido (razão de ser) da execução concursal.

Ainda nos dizeres de GONTIJO (2007):

Ora, se a execução trabalhista pudesse ser redirecionada após a declaração da falência do empregador, a ordem dos privilégios (dentre eles a havida para o mesmo empregado e antes demonstrada) e até mesmo a lógica do sistema falimentar, que se assenta no concurso de credores e na par conditio creditorum, restaria frustrada. A 


\begin{abstract}
falência, que é o processo que, por excelência, visa a assegurar a implementação dos privilégios e garantias, restaria bastante esvaziado.

Não nos esqueçamos também que, a desconsideração da personalidade jurídica por um juízo trabalhista poderia redundar na negativa de vigência da ordem de privilégio dos créditos na falência, uma vez que poderia haver o pagamento da integralidade do crédito trabalhista (até mesmo superior aos 150 salários mínimos) em detrimento de outros credores cujo privilégio supera ao trabalhista.
\end{abstract}

Entendimento em sentido contrário, como já dito, só trará privilégios à classe dos credores trabalhistas, que terão muito mais chances de receber seus créditos (e de forma integral), já que, não raro, os juízes trabalhistas têm promovido a desconsideração da personalidade jurídica, de forma a alcançar também os bens particulares dos sócios da sociedade empresária falida e, em alguns casos, de sociedades empresárias pertencentes ao mesmo grupo econômico da falida.

Isso sem contar que a satisfação dos créditos trabalhistas, nestas hipóteses, se verificará em um espaço de tempo muito menor do que a daqueles credores que foram obrigados a se sujeitar ao moroso procedimento falimentar.

Com efeito, privilégio tamanho deve ser repudiado, vez que, como já dito, afronta o próprio sentido da lei falimentar que é a execução concursal e a paridade entre os credores.

Permitir que a justiça laboral prossiga com a execução dos créditos trabalhistas quando há um juízo universal onde tramitam todas as demais execuções contra o devedor falido é subverter a vontade do legislador, pois, além do privilégio legal já concedido ao crédito trabalhista pela Lei 11.101/05, estar-se-á criando uma preferência absoluta para essa classe de credores, que, por vias transversas, poderá satisfazer seu crédito sem submeter-se à habilitação junto à massa falida.

A conclusão a que se pode chegar, depois de tudo o que foi exposto, é que a Justiça Laboral não perderá sua competência para decidir questões trabalhistas em face de empresas falidas, mas sim que essa competência será limitada ao momento de apuração do crédito devido do reclamante naquela ação. A partir deste momento, a competência é transferida ao Juízo Falimentar.

\title{
6. O ENTENDIMENTO JURISPRUDENCIAL SOBRE O TEMA
}

Como já dito, não obstante o entendimento doutrinário majoritário sobre o tema; não obstante já haver o STF, inclusive, se manifestado sobre a questão, o que se observa é que guns juízes e também tribunais continuam seguindo entendimento diverso, permitindo que 
as execuções trabalhistas prossigam no juízo laboral.O TRT da $3^{\text {a }}$ região, recentemente, publicou o seguinte acórdão:Data de Publicação: 25/11/2014
Disponibilização: $\quad$ 24/11/2014
Fonte: DEJT/TRT3/Cad.Jud. Página 308. Boletim: Não.
Órgão Julgador: Setima Turma
Relator: $\quad$ Fernando Luiz G.Rios Neto
Revisor: $\quad$ Paulo Roberto de Castro
Tema: EXECUÇÃO - DEVEDOR SOLIDÁRIO
EMENTA: FALÊNCIA DA DEVEDORA PRINCIPAL. PROSSEGUIMENTO DA EXECUÇÃO EM FACE DOS DEVEDORES SOLIDÁRIOS. COMPETÊNCIA DA JUSTIÇA DO TRABALHO. A decretação de falência suspende a execução apenas em face do devedor falido, nos termos do artigo $6^{\circ}$ e 76 , da Lei 11.101, de 09 de fevereiro de 2005. Diante disso, não há óbice ao prosseguimento da execução contra os demais executados. Aliás, com o cancelamento da Súmula n. 205, do TST abriu-se a possibilidade de se incluir empresa solvente do mesmo grupo econômico da devedora principal para garantir a satisfação do crédito trabalhista, notadamente, quando há falência da devedora principal, como in casu. Dessa forma, prossegue-se a execução contra os devedores solidários solventes nesta Justiça Especializada, inclusive contra a ora agravante, empresa integrante do mesmo grupo econômico da devedora principal, a teor do art. 475-P, do CPC c/c arts. $6^{\circ}$ e 76, da Lei 11.101/05.

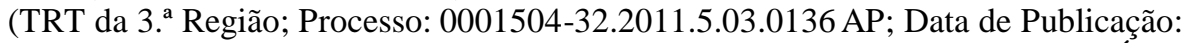 25/11/2014; Disponibilização: 24/11/2014, DEJT/TRT3/Cad.Jud, Página 308; Órgão Julgador: Setima Turma; Relator: Fernando Luiz G.Rios Neto; Revisor: Paulo Roberto de Castro) ${ }^{2}$ (negrito nosso)

Conforme se vê, o entendimento adotado pela Sétima Turma foi no sentido de possibilitar o prosseguimento da execução, desconsiderando-se a personalidade jurídica da sociedade empresária falida, com o objetivo de perseguir os bens particulares dos sócios bem como de demais empesas do grupo econômico.

Já a Segunda Turma do mesmo TRT3, em entendimento alinhado com o do STF, assim decidiu:

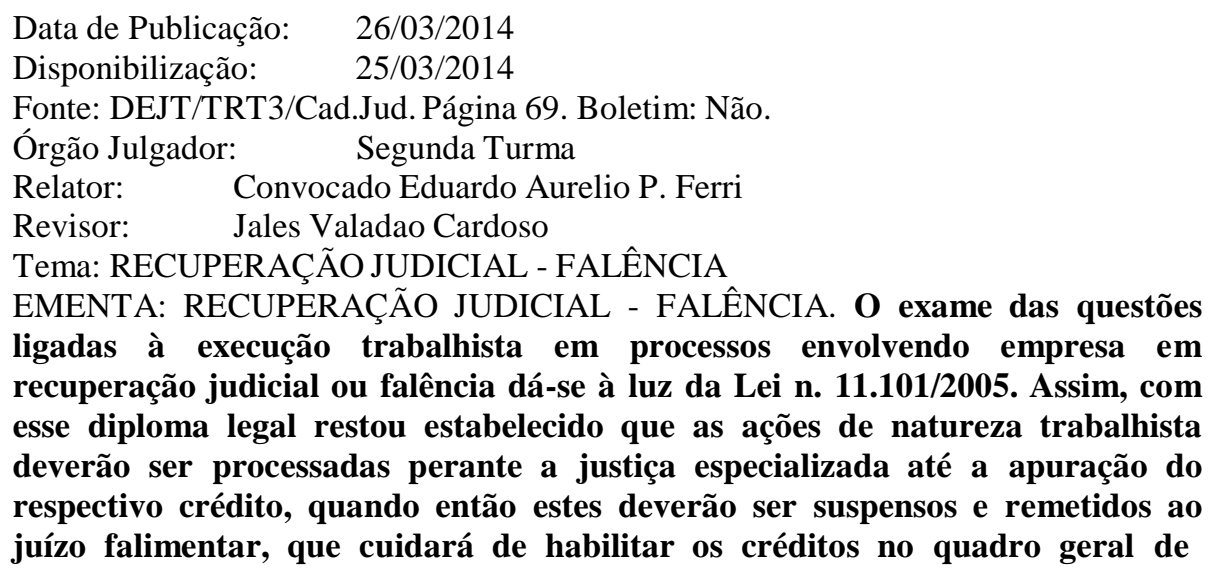

\footnotetext{
${ }^{2}$ Disponível em:

http://as1.trt3.jus.br/consulta/redireciona.htm?pIdAcordao=1131879\&acesso=1c4defb185e44022aa4814a3934f1 a42. Acesso em 17/08/2015, às 11:10.
} 
credores, de acordo com o disposto no parágrafo único do artigo 76. Nesse sentido, a jurisprudência da Corte Superior: "AGRAVO DE INSTRUMENTO EM RECURSO DE REVISTA. EXECUÇÃO FISCAL. MULTA ADMINISTRATIVA. MASSA FALIDA. HABILITAÇÃO NO JUÍZO FALIMENTAR. Esta Justiça Especializada não detém competência para proceder à execução contra a massa falida, cabendo tal prerrogativa ao Juízo falimentar. A atuação da Justiça do Trabalho, à luz do art. 114 do Texto Constitucional e das disposições da Lei de Recuperação Judicial, Extrajudicial e de Falência (Lei n. 11.101/05), vai até à individualização e quantificação do crédito, passando, por conseguinte, à sua habilitação no quadro geral de credores. A determinação de habilitação do crédito no Juízo falimentar não ofende, assim, à literalidade do art. 114, VIII, da Constituição Federal. Agravo de Instrumento não provido". (TST - Processo: AIRR - 1615-52.2010.5.03.0103 Data de Julgamento: 29/08/2012, Relatora Ministra: Maria de Assis Calsing, 4ª Turma, Data de Publicação: DEJT 31/08/2012). (TRT da 3. ${ }^{a}$ Região; Processo: 0001023-70.2012.5.03.0092 AP; Data de Publicação: 26/03/2014; Disponibilização: 25/03/2014, DEJT/TRT3/Cad.Jud, Página 69; Órgão Julgador: Segunda Turma; Relator: Convocado Eduardo Aurelio P. Ferri; Revisor: Jales Valadao Cardoso) ${ }^{3}$ (negrito nosso)

As Turmas do TRT1 também vêm decidindo no sentido de que é do juízo falimentar a competência para prosseguir com a execução dos créditos trabalhistas, senão vejamos:

FALÊNCIA DA EXECUTADA. PROSSEGUIMENTO DA EXECUÇÃO EM FACE DOS SÓCIOS. IMPOSSIBILIDADE. Decretada a falência da reclamada, a execução deve prosseguir perante o Juízo da Falência, mediante a habilitação do credor na Massa Falida. A responsabilidade dos sócios pelas dívidas trabalhistas da sociedade é subsidiária, portanto, apenas restando definitivamente comprovada no Juízo Falimentar a inexistência de patrimônio da empresa capaz de saldar os créditos habilitados, poderá aquele Juízo executar os bens dos sócios, desconsiderando a personalidade jurídica da empresa.

(TRT da 1. ${ }^{a}$ Região; Processo: Agravo de Petição no 0003000-28.2009.5.01.0070 RTOrd; Data de Publicação: 07/07/2014; Órgão Julgador: Quarta Turma; Relatora: Monica Batista Vieira Puglia) ${ }^{4}$ (negrito nosso)

JUÍZO UNIVERSAL FALIMENTAR. ARRESTO REALIZADO EM MOMENTO ANTERIOR À DECRETAÇAO DA FALÊNCIA. Havendo a decretação de falência da executada, a competência para atos de execução, a partir desse momento, passa a ser do juízo universal da falência, ainda que exista alguma garantia anteriormente determinada por outro juízo, nos termos do artigo $6^{\circ}$, da Lei 11.101/05. A demanda trabalhista prosseguirá na Justiça do Trabalho até a apuração do crédito do obreiro, que deverá ser habilitado no juízo falimentar. A decretação da falência atribui competência ao juízo universal para distribuir o patrimônio da massa falida aos credores, de acordo com a classificação dos créditos, delineada nos artigos 83 e seguintes da Lei 11.1101/05. Ainda que a prenotação no imóvel tenha sido realizada em momento anterior, a superveniência da decretação de falência da empregadora torna inviável o prosseguimento de atos de expropriação patrimonial contra a massa falida em juízo

\footnotetext{
Disponível em

http://as1.trt3.jus.br/consulta/redireciona.htm?pIdAcordao=1076738\&acesso=b1aa61e 8f6852df31dedd1957e3dc 66c. Acesso em 17/08/2015, às 11:04.

${ }^{4}$ Disponível em

http://bd1.trt1.jus.br/xmlui_portal/bitstream/handle/1001/567710/00030002820095010070\%2307-07-

2014.pdf? sequence=1\&\#search=. Acesso em 28/03/2015 às 22:16.
} 
diverso ao falimentar, notadamente considerando-se que sequer houve realização de penhora.

(TRT da 1. ${ }^{\text {a }}$ Região; Processo: TRT-AP-0000001-61.2014.5.01.0221; Data de Publicação: 19/02/2015; Órgão Julgador: Segunda Turma; Relator: Volia Bomfim Cassar) ${ }^{5}$

O TRT2 também vem decidindo que as execuções devem prosseguir no juízo universal da falência e somente após finalizado o processo falimentar é que se pode dar prosseguimento às execuções na justiça laboral contra os sócios e, eventualmente, contra outras empresas do mesmo grupo econômico.

CRÉDITO TRABALHISTA. ORDEM DE EXECUÇÃO. HABILITAÇÃO NO JUIZO DE RECUPERAÇÃO JUDICIAL, EXTRAJUDICIAL E FALENCIA. Decretada a falência do devedor principal, o credor trabalhista deverá habilitar seu crédito perante o Juízo de Recuperação judicial, Extrajudicial e Falência. Eventual expropriação do patrimônio de devedor subsidiário ou de sócios do devedor principal somente poderá ocorrer após o encerramento do processo de falência. Incidência da lei 11.101.2005.

(TRT da 2. ${ }^{a}$ Região; Processo: 0023500-62.1995.5.02.0011; Data de Publicação: 17/03/2015; Órgão Julgador: Terceira Turma; Relatora: Mércia Tomazinho) ${ }^{6}$

A discussão no TRT4 já parece pacificada. O entendimento que prevalece nesta instância superior é de que as execuções dos créditos trabalhistas devem ocorrer perante o juízo universal da falência, competindo à justiça especializada somente o julgamento do processo de conhecimento. Vejamos:

\footnotetext{
Acórdão - Processo 0048900-86.2007.5.04.0016 (AP)

Data: 06/05/2014 Origem: $16^{\mathrm{a}}$ Vara do Trabalho de Porto Alegre

Órgão julgador: SECAO ESPECIALIZADA EM EXECUCAO

Redator: ANA ROSA PEREIRA ZAGO SAGRILO

AGRAVO DE PETIÇÃO DA EXECUTADA VRG LINHAS AÉREAS S.A. INCOMPETÊNCIA DA JUSTIÇA DO TRABALHO. PROCESSAMENTO DA EXECUÇÃO. EMPRESA SUJEITA AO REGIME FALIMENTAR. Diante do julgamento do Recurso Extraordinário $\mathrm{n}^{\circ}$ 583.955-9, pelo STF, de relatoria do Ministro Ricardo Lewandowski, que julgou conflito de competência entre a Justiça do Trabalho e a Justiça Estadual Comum ( $1^{\mathrm{a}}$ Vara Empresarial da Comarca do Rio de Janeiro) e das reiteradas decisões do STJ no mesmo sentido, conclui-se pertencer ao juízo universal da falência a competência material para execução dos créditos trabalhistas, sem prejuízo da competência da Justiça do Trabalho para o julgamento do processo de conhecimento. (...)

Trecho pesquisado: PROCESSO: 0048900-86.2007.5.04.0016 AP. EMENTA. AGRAVO DE PETIÇÃO DA EXECUTADA VRG LINHAS AÉREAS ...7
}

\footnotetext{
${ }^{5}$ Disponível em

http://bd1.trt1.jus.br/xmlui_portal/bitstream/handle/1001/605348/00000016120145010221\%2319-02-

2015.pdf?sequence=1\&\#search=brashopping participacoes Itda. Acesso em 28/03/2015 às 22:22.

${ }^{6}$ Disponível em http://www.trtsp.jus.br/pesquisa-jurisprudencia-por-palavra-acordaos. Acesso em 28/03/2015 às 22:47
} 
Já no TRT da $5^{\text {a }}$ Região, a Segunda e Quarta Turmas entendem que a execução pode prosseguir na Justiça do Trabalho, desde que contra os bens pessoais dos sócios e até de outras empresas pertencentes ao mesmo grupo econômico, mediante a desconsideração da personalidade jurídica, já que estes não são falidos. Se a executada for apenas a sociedade empresária falida, nessa hipótese a competência será do juízo falimentar.

AGRAVO DE PETIÇÃO. NÃO PROVIDO. JUROS DE MORA. RESPONSABILIDADE SUBSIDIÁRIA. Ao devedor subsidiário não é aplicável o quanto disposto no art. 124 da Lei $n^{\circ}$. 11.101/2005 (Lei de Falências), que confere o privilégio exclusivamente à massa falida, não havendo falar em limitação de juros à data da decretação da falência da primeira Reclamada, devedora principal, quando do redirecionamento da execução da segunda Reclamada, responsável subsidiária.

Processo 0000012-78.2011.5.05.0029 AP, Origem SAMP, ac. no 219340/2014, Relatora Desembargadora LOURDES LINHARES , $4^{\text {a }}$. TURMA, DJ 28/10/2014. ${ }^{8}$ (negrito nosso)

RECUPERAÇÃO JUDICIAL. INCOMPETÊNCIA DA JUSTIÇA DO TRABALHO PARA ATOS DE CONSTRIÇÃO APÓS EMISSÃO DE CERTIDÃO PARA HABILITAÇÃO DO CRÉDITO PERANTE JUÍZO FALIMENTAR. EXCEÇÃO. Não obstante seja o Juízo Falimentar competente para processar a execução do título executivo judicial produzido pela Justiça do Trabalho, excepcionalmente, quando houver penhora de bens efetivada antes da decretação da falência da empresa, a competência para prosseguir com os atos de execução é da Justiça do Trabalho.

Processo 0000943-29.2011.5.05.0014 AP, Origem SAMP, ac. $\mathrm{n}^{\circ}$ 197017/2014, Relatora Desembargadora LUÍZA LOMBA , 2 ${ }^{\mathrm{a}}$. TURMA, DJ 25/07/2014. ${ }^{9}$ (negrito nosso)

Já a Terceira e Quinta Turmas do TRT5 entendem em sentido diverso, o que demonstra que não há um consenso neste Tribunal Superior, senão vejamos:

AGRAVO DE PETIÇÃO - REDIRECIONAMENTO DA EXECUÇÃO CONTRA O SÓCIO - Decretada a falência da executada, os créditos deferidos ao autor deverão ser habilitados junto à massa, afigurando-se inviável o redirecionamento da execução contra o sócio.

\footnotetext{
${ }^{7}$ Disponível em

http://www.trt4.jus.br/portal/portal/trt4/consultas/jurisprudencia/gsaAcordaos/ConsultaHomePortletWindow;jses sionid=49ECDF759131EF1402644D35380193D0.jbportal-103 ?action=2. Acesso em 28/03/2015 às 22:05

${ }^{8}$ Disponível em

http://www.trt5.jus.br/jurisprudencia/modelo/AcordaoConsultaBlobTexto.asp?v_id=633669\&texto=execu\%E7\% E3o\%20and\%20fal\%EAncia. Acesso em 28/03/2015 às 22:59.

${ }^{9}$ Disponível em

http://www.trt5.jus.br/jurisprudencia/modelo/AcordaoConsultaBlobTexto.asp?v_id=596534\&texto=execu\%E7\% E3o\%20and\%20fal\%EAncia. Acesso em 28/03/2015 às 23:04.
} 
Processo 0040100-25.2009.5.05.0193 AP, Origem SAMP, ac. no 160443/2013, Relatora Desembargadora MARIZETE MENEZES , $3^{\text {a }}$. TURMA, DJ 23/08/2013. ${ }^{10}$ (negrito nosso)

MASSA FALIDA. ATOS DE EXECUÇÃO. INCOMPETÊNCIA DA JUSTIÇA DO TRABALHO. A Justiça do Trabalho é competente para apreciar as ações que tenham por objeto a certificação e a liquidação dos créditos decorrentes das relações de emprego mantidas com empresas em processo de falência, carecendo de competência, contudo, para os atos de execução dos haveres trabalhistas devidos por empresas nesta peculiar condição, conforme previsto no art. $\mathbf{6}^{\mathbf{0}}, \S \mathbf{2}^{\mathbf{0}}$, da Lei 11.101/2005. Processo 0051000-64.1996.5.05.0018 AP, Origem SAMP, ac. $\mathrm{n}^{\mathrm{o}}$ 159449/2013, Relator Desembargador PAULINO COUTO, $5^{\text {a }}$ TURMA, DJ 19/08/2013. ${ }^{11}$ (negrito nosso)

\section{CONCLUSÕES}

Depois de tudo o que foi dito e demonstrado, a conclusão a que se pode chegar é que, ainda hoje, mesmo após já ter o STF se manifestado sobre a questão da incompetência da Justiça do Trabalho para prosseguir com as execuções fiscais quando a devedora principal é uma sociedade empresária falida, os juízos trabalhistas de primeiro grau ainda insistem em dar prosseguimento a estas execuções, violando todo um naipe de normas específicas que regulam a falência.

Pior, violando o princípio maior que é o da paridade com que devem ser tratados todos os credores em um processo de execução concursal.

Com efeito, uma vez declarada a falência de uma sociedade empresária, todas as execuções trabalhistas devem ser imediatamente suspensas, e os respectivos créditos habilitados no juízo falimentar, de forma que a estes credores seja dado o mesmo tratamento (ressalvadas as preferências legais) conferido aos demais.

Como já dito alhures, o prosseguimento das execuções de créditos trabalhistas na própria justiça laboral confere um privilégio mais que especial a estes créditos (que já têm seu privilégio assegurado no procedimento falimentar), na medida em que, uma vez desconsiderada a personalidade jurídica da sociedade empresária falida, estes credores conseguem atingir os bens particulares dos sócios e, também, de outras empresas do mesmo grupo econômico, quando for o caso, o que pode frustrar eventual pedido de desconsideração

\footnotetext{
${ }^{10}$ Disponível em 28/03/2015 às 23:14 em

http://www.trt5.jus.br/jurisprudencia/modelo/AcordaoConsultaBlobTexto.asp?v_id=471139\&texto=execu\%E7\% E3o\%20and\%20fal\%EAncia. Acesso em 28/03/2015 às 23:14.

${ }^{11}$ Disponível em

http://www.trt5.jus.br/jurisprudencia/modelo/AcordaoConsultaBlobTexto.asp?v_id=469460\&texto=execu\%E7\% E3o\%20and\%20fal\%EAncia. Acesso em 28/03/2015 às 23:17.
} 
da personalidade jurídica, com extensão dos efeitos da falência aos sócios e outras empresas do mesmo grupo, pelo juízo falimentar.

O que ocorrerá, nestas hipóteses, é que o juízo falimentar, ao tentar arrecadar o patrimônio pessoal dos sócios e, eventualmente, de outras empresas do mesmo grupo econômico, possivelmente pouco ou nada encontrará, já que o ativo existente já terá sido expropriado para a garantia de alguns credores trabalhistas apenas, credores estes que, em ofensa à par conditio creditorum, não se submeteram ao moroso procedimento falimentar.

Assim, conclui-se não ser possível o redirecionamento das execuções trabalhistas, pelo próprio juiz do trabalho, contra quem quer que seja (sócios, terceiros, empresas do mesmo grupo econômico), porquanto tal expediente é ato executivo para o qual a Justiça do Trabalho não possui competência, insista-se!

A se permitir que essa prática se legitime, estar-se-á conferindo maiores privilégios aos credores trabalhistas (violando a par conditio creditorum), que poderão receber seus créditos em detrimento dos demais.

Isso sem contar que, em eventual hipótese de desconsideração da personalidade jurídica e extensão dos efeitos da falência promovida pelo próprio juízo falimentar, estes expedientes podem restar frustrados, por já terem sido excutidos todos os bens dos terceiros e sócios eventualmente responsabilizados.

Aliás, essa prática pode abrir inúmeras possibilidades de fraude contra os credores da massa, o que não pode ser admitido.

Assim, uma vez tornado líquido o crédito trabalhista, deve ele ser habilitado junto à falência, não detendo o juízo trabalhista competência para prosseguir com a respectiva execução (nem mesmo para redirecioná-la contra pessoa diversa do devedor falido), que deverá permanecer suspensa até que se encerre o procedimento falimentar.

\section{BIBLIOGRAFIA}

BESSONE, Darcy. Instituições de Direito Falimentar. São Paulo: Saraiva, 1995.

BRASIL. Lei 11.101 de 9 de fevereiro de 2005. Regula a recuperação judicial, a extrajudicial e a falência do empresário e da sociedade empresária. Disponível em http://www.planalto.gov.br/ccivil_03/_ato2004-2006/2005/lei/111101.htm. Acesso em 02/08/2015, às 01:38h.

CAMPINHO, Sérgio. Falência e recuperação de empresa: o novo regime da insolvência empresarial. $3^{\text {a }}$ ed. Rio de Janeiro: Renovar: 2008. 
CARRION, Valentim. Comentários à CLT: legislação complementar - jurisprudência. 39a ed. rev. e atual. São Paulo: Saraiva, 2014.

COELHO, Fábio Ulhoa. Comentários à nova lei de falências e de recuperação de empresas. 2 . ed. São Paulo: Saraiva, 2005.

. Lei de Falências e de recuperação de empresas (Lei 11.101 de 9.2.2005). São Paulo: Saraiva, 2005.

. Curso de direito comercial. V.3. 6 ${ }^{\text {a }}$ ed., rev. e atual. São Paulo: Saraiva, 2006.

DELGADO, Mauricio Godinho. Curso de Direito do Trabalho. 13a ed. São Paulo: LTr, 2014.

GONTIJO, Vinícius José Marques. Efeitos da falência do empregador na ação de execução de crédito trabalhista. Revista de Direito do Trabalho, São Paulo, v. 33, n. 128, p. 229-252, out./dez. 2007.

JUNIOR, Ecio Perin. Curso de Direito Falimentar: atualizado de acordo com o novo código civil (Lei 10.406/2002). 2a ed. rev. atual. e ampliada. São Paulo: Editora Método, 2004.

JUNIOR, Francisco Satiro de Souza (org.); PITOMBO, Antônio Sérgio A. de Moraes (org.). Comentários à Lei de Recuperação de Empresas e Falência. Lei 11.101/05 - Artigo por artigo. $2^{a}$ ed. rev. e atual. e ampl. São Paulo: Editora Revista dos Tribunais, 2007.

LIMA, Osmar Brina Corrêa (org.); LIMA, Sérgio Mourão Corrêa (org.). Comentários à nova lei de falência e recuperação de empresas: Lei 11.101, de 09 de fevereiro de 2005 . Rio de Janeiro: Forense, 2009.

MARCATO, Tércio Túlio Nunes. A Competência no Juízo Falimentar. RDE No 26 - MaioJun/2012 - ASSUNTO ESPECIAL - DOUTRINA. Disponível em http://bdjur.tjdft.jus.br/xmlui/bitstream/handle/123456789/14882/A\%20compet\%C3\%AAncia $\% 20 \mathrm{no} \% 20 \mathrm{ju} \% \mathrm{C} 3 \% \mathrm{ADzo} \% 20 \mathrm{falimentar}$.pdf?sequence $=1 \quad$ e em http://www.sintese.com/doutrina_integra.asp?id=1219

PACHECO, José da Silva. Processo de falência e concordata: comentários à lei de falências: doutrina, prática e jurisprudência. Rio de Janeiro: Forense, 2000.

. Processo de recuperação judicial, extrajudicial e falência: em conformidade com a Lei $n^{\circ} 11.101 / 05$ e a alteração da Lei no 11.127/05. Rio de Janeiro: Forense, 2006.

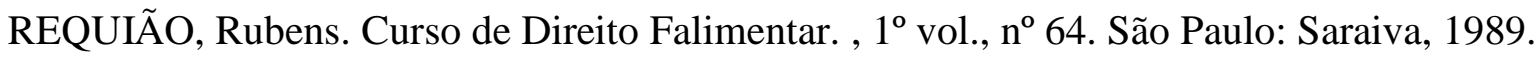

TOMAZETTE, Marlon. Curso de direito empresarial, volume 3: falência e recuperação de empresas. $3^{a}$ ed., São Paulo: Atlas, 2014.

VALVERDE, Trajano de Miranda. Comentários à lei de falências: (Decreto-Lei no 7.661, de21 de junho de 1945). $4^{\text {a }}$ ed. rev. atual. por J. A. Penalva Santos e Paulo Penalva Santos. Rio de Janeiro: Forense, 1999. 